Dirāsāt: Jurnal Manajemen dan Pendidikan Islam, Vol. 6, No. 2, Desember 2020: 119-131. ISSN (Online): 2550-1038, ISSN (Print): 2503-3506. Website: journal.unipdu.ac.id/index.php/dirasat/index. Dikelola oleh Program Studi Manajemen Pendidikan Islam (MPI) Program Pascasarjana Universitas Pesantren Tinggi Darul Ulum (Unipdu) Jombang Indonesia.

\title{
Home Visit sebagai Refleksi Kurikulum Darurat Covid-19: Kesiapan Guru, Respon Siswa, Materi dan Hasil Belajar di Madrasah Tsanawiyah
}

\section{Intan Safitri Mokodompit}

Madrasah Tsanawiyah Negeri 1 Kotamobagu

Email: intan.safitri079@gmail.com

Abstrak: MTs N 1 Kotamobagu menerapkan program home visit sebagai salah satu solusi mengatasi kesulitan belajar siswa dan merupakan tindakan preventif mengurangi miskomunikasi antara guru dan siswa dalam pembelajaran online dimasa pandemi Covid-19. Kegiatan ini juga dilakukan untuk mendapatkan keterangan-keterangan atau data yang dibutuhkan dalam memahami lingkungan dan kondisi belajar siswa selama diterapkannya pembelajaran jarak jauh di masa pandemi Covid-19. Dengan demikian, dalam rangka evaluasi tentang efektifitas proses pembelajaran demi meningkatkan pelayanan pendidikan dan pengajaran di MTs $\mathrm{N} 1$ Kotamobagu pada masa Covid-19, mengingat terdapat berbagai fenomena yang dihadapi oleh guru dan siswa dalam pembelajaran online dan pelaksanaan program home visit, maka penulis melakukan eksplanasi pedagogik dengan paradigma positivistik pada kebijakan madrasah dalam kegiatan home visit sebagai refleksi kurikulum darurat Covid-19 dengan mengukur tingkat kesiapan guru, respon siswa, materi dan hasil belajar di MTs N 1 Kotamobagu dengan skala pengukuran atau rating scale penelitian kualitatif deskriptif melalui penyebaran angket sebagai penguatan data pada hasil pengamatan dan wawancara. Hasil penelitian menunjukan bahwa pelaksanaan home visit membantu guru dalam mendapatkan informasi tentang keluhan siswa dan orang tua selama pembelajaran jarak jauh dimasa pandemi Covid-19, meskipun pada pelaksanaanya home visit terasa kurang maksimal dilakukan karena rasio jumlah guru dan siswa tidak seimbang. Guru Madrasah Tsanawiyah Negeri 1 Kotamobagu memiliki tingkat kesiapan dengan kategori $80,10 \%$ guru siap dalam pelaksanaan home visit dengan respon siswa terhadap program home visit $79,17 \%$ siswa merespon dengan baik, sementara materi pelajaran hanya $65 \%$ yang tersampaikan dari target yang diharapkan dengan presentase target pencapaian hasil belajar $69 \%$.

Kata kunci: Home visit, kurikulum, Covid-19.

Abstract: MTs N 1 Kotamobagu applied home visit program as a solution to overcome students learning difficulties and as an action of prevention to decrease miscommunication between teachers and students in online learning during pandemic Covid-19 situation. This action also conducted to obtain information or data that necessary for understanding the environment and condition of students learning in the application of distance learning during pandemic Covid-19 situation. Therefore, in order to evaluate the effectiveness of learning process for increasing educational service and teaching in MTs N 1 Kotamobagu during pandemic Covid-19 situation, considering the availability of various phenomenon that faced by teachers and students in online learning and application of home visit program, then, writer conducted pedagogic explanation through the positivistic paradigm in Islamic School regulation in home visit program as the reflection of urgent curriculum of Covid-19 by measuring the level of teachers' readiness, students' responses, materials and results of study in MTs N 1 Kotamobagu with the scale of measuring or rating scale of quantitative descriptive research through spreading questionnaire as strengthening data in the result of observation and interview. The research result presented that the application of home visit helped teachers in obtaining information about students and parents challenges during distance learning in pandemic Covid-19 situation, although in the application of home visit felt not quite maximal to be conducted due to the ratio of teachers and students amount are unbalance. Teachers of Madrasah Tsanawiyah Negeri 1 Kotamobagu have level of readiness in category $80.10 \%$ teachers were ready in applying home visit with the responses of 
students toward the home visit program $79.17 \%$ students kindly responded, while the learning material only reached $65 \%$ that been delivered from the target expected with the target presentation learning result reached $69 \%$.

Keywords: Home visit, curriculum, Covid-19.

\section{Pendahuluan}

Peraturan Menteri Agama Republik Indonesia Nomor 60 Tahun 2015 Tentang Penyelenggaraan Pendidikan Madrasah. Madrasah adalah satuan pendidikan formal dalam binaan Menteri Agama yang menyelenggarakan pendidikan umum dan kejuruan dengan kekhasan Agama Islam yang mencakup Raudhatul Athfal (RA), Madrasah Ibtidaiyah (MI), Madrasah Tsanawiyah (MTs), Madarasah Aliyah (MA) dan Madrasah Aliyah Kejuruan (MAK). Sistem pendidikan model madrasah bermunculan, sebagaimana halnya pesantren. Kemunculan madrasah ini minimal dapat dilihat dari dua sisi. Pertama, ia sebagai salah satu bentuk pengembangan yang berasal dari pesantren. Kedua madrasah lahir dari luar pesantren, seperti organisasi sosial keagaman atau organisasi sosial politik. ${ }^{1}$ Dalam konteks ini kelahiran madrasah bukan merupakan kelanjutan dari sistem pesantren, melainkan sistem pendidikan yang berdiri sendiri. Dan hingga saat ini pendidikan di Madrasah terus berjalan proses belajar mengajarnya. Namun, di masa pandemi ini banyak sekolah dan perguruan tinggi harus meliburkan siswa maupun mahasiswanya dan menggantinya dengan belajar mengajar secara online untuk mencegah penyebaran corona virus desease (Covid-19).

Penyebaran virus corona semakin bertambah dari waktu ke waktu. Berbagai upaya dilakukan oleh pemerintah untuk mengatasi penyebaran virus, diantaranya terdapat kebijakan pendidikan dalam masa darurat penyebaran Covid-19. Pemerintah menginstruksi beberapa kebijakan pencegahan virus corona di lingkungan pendidikan antara lain: (a) meningkatkan peran sekolah dalam melengkapi fasilitas pelayanan kesehatan sebagai usaha pencegahan penyebaran Covid-19; (b) menyiapkan sarana untuk cuci tangan pakai sabun dan alat pembersih sekali pakai seperti tisu dan kain diberbagai lokasi strategis disatuan pendidikan; (c) memastikan pihak sekolah melakukan pembersihan ruangan dan lingkungan sekolah secara rutin terutama pada fasilitas lain yang sering terpegang oleh tangan; (d) mengingatkan seluruh warga sekolah untuk menghindari kontak fisik secara langsung. ${ }^{2}$

Pemerintah dan masyarakat di Kota Kotamobagu juga melakukan upayaupaya pencegahan penyebaran virus corona mengikuti arahan pemerintah pusat. Hal ini dilakukan oleh masyarakat dengan mematuhi protokoler kesehatan yang dikeluarkan oleh pemerintah setempat, sementara pihak pemerintah melakukan pengawasan atau pemantauan terhadap masyarakat,

\footnotetext{
${ }^{1}$ Assegaf Rahman Abdur, Pendidikan Islam di Indonesia (Yogyakarta: Suka Press, 2017), 30.

${ }^{2}$ Kementerian Kesehatan RI, Pedoman Pencegahan dan Pengendalian Coronavirus Disease (COVID-19) Revisi Ke-4 (Direktorat Jenderal Pencegahan dan Pengendalian Penyakit (P2P), 2020).
} 
mengingat peningkatan penyebaran virus begitu menghawatirkan. Surat Edaran Nomor 3 Tahun 2020 pada Satuan Pendidikan dan Nomor 36962/MPK.A/HK/2020 tentang Pelaksanaan Pendidikan dalam Masa Darurat Corona Virus Disease (Covid-19) menyebutkan bahwa kegiatan belajar dilakukan secara daring (online) dalam rangka pencegahan penyebaran Covid19. Madrasah-madrasah di Kota Kotamobagu juga mendapat perhatian lebih dalam penerapan kebijakan agar tidak menjadi klaster baru dalam penyebaran virus corona.

Siswa-siswi MTs Negeri 1 Kotamobagu diintruksikan untuk belajar dari rumah melalui sistem jaringan internet, meskipun pada beberapa kesempatan atau kegiatan membolehkan siswa untuk datang ke madrasah dengan tetap memperhatikan protokoler kesehatan dalam pencegahan penyebaran virus corona. Pada kenyataannya virus corona menjadi topik yang selalu membayangi dalam setiap kebijakan madrasah untuk melaksanakan fungsinya. Pembelajaran yang ditawarkan dalam bentuk online, efisiensi dan efektifitas pengelolaan informasinya menjadi krusial. Sebelum dilaksanakannya pembelajaran online, perlu adanya perancangan media pembelajaran yang dilakukan oleh guru, yang harus mampu menjawab pertanyaan: bagaimana bentuk materi yang akan disampaikan, kegiatan belajar seperti apa yang akan siswa lakukan. Pertanyaan-pertanyaan inilah yang mendasari guru dalam merancang sebuah model pembelajaran yang tepat dalam proses pembelajaran online. Melirik pada pernyataan bahwa hasil belajar lebih banyak dipengaruhi oleh berbagai bentuk rancangan konsep dan strategi pembelajaran dari pada jenis media atau teknologi yang digunakan untuk menyampaikan materi pembelajaran, ${ }^{3}$ dan studi meta-analisis yang dilakukan terhadap penelitian media pembelajaran menunjukkan bahwa siswa mendapatkan hasil belajar yang signifikan dari media audio visual atau komputer bukan karena media yang digunakan tetapi karena bentuk dan susunan strategi dalam pembelajaran. Hal ini menunjukkan bahwa rancangan strategi pembelajaran dan desain media pembelajaran akan sangat menentukan keberhasilan belajar siswa, maka dengan demikian guru wajib mengasah kemampuan untuk meningkatkan kualitas proses, memantapkan persiapan bahan ajar dan penguatan strategi dalam pembelajaran online.

Pemanfaatan kelas online sebagai sarana belajar ini akan lebih baik lagi dengan adanya kerjasama dan bimbingan orang tua. Hal ini juga yang menginspirasi guru-guru madrasah untuk melakukan beberapa terobosan dalam proses pembelajaran agar siswa-siswi madrasah tetap belajar walaupun mereka berada di rumah, karena proses pembelajaran dilakukan melalui jaringan internet (tatap maya) dengan memanfaatkan aplikasi WhatsApp, Google Classroom, dan aplikasi lainnya yang mendukung proses pembelajaran.

\footnotetext{
${ }^{3}$ Danerson Terry, The Theory dan Practice of Online Learning, 2nd ed. (Edmonton: Athabasca University Press, 2008), 28; Nurhayati., dkk, Rancangan Model Pembelajaran Kelas Maya Melalui Rumah Belajar Sebagai Program Remedial (Jakarta: Pusat Teknologi Informasi dan Komunikasi Pendidikan dan Kebudayaan, 2018).
} 
Suasana diciptakan sedemikian adanya agar siswa tetap belajar. Tatap maya atau kelas maya (virtual class) adalah lingkungan belajar yang diadakan tanpa tatap muka secara langsung antara guru dengan siswa. Virtual class bisa digunakan dalam pembelajaran kelas langsung (tatap muka) dan digunakan untuk pembelajaran online antara siswa dengan guru. Kelas maya merupakan bentuk pemanfaatan teknologi informasi dibidang pendidikan, selain itu juga merupakan perubahan proses belajar mengajar konvensional menjadi bentuk online. ${ }^{4}$ Pembelajaran online (juga dikenal dengan e-learning) merupakan bentuk pembelajaran yang dilaksanakan secara elektronik dengan menggunakan komputer dan berbasis online. Bahan ajar atau materi pembelajaran bisa diakses melalui sebuah jaringan. Sumbernya bisa berasal dari website, internet, intranet, CD-ROM, dan DVD. Selain memberikan instruksi, e-learning juga dapat mengevaluasi proses pembelajaran siswa dan melaporkan kemajuan siswa. E-learning adalah suatu kemajuan penting dalam sistem pendidikan modern. E-learning ini membawa pengaruh terjadinya proses transformasi pendidikan konvensional ke dalam bentuk digital, baik secara isi (contents) maupun sistemnya. E-learning adalah suatu jenis belajar mengajar yang memungkinkan tersampaikannya bahan ajar ke siswa dengan menggunakan media internet. ${ }^{5}$

Madrasah menjadi penyelenggara kelas online, karena madrasah memiliki akses mengelola keseluruhan sistem informasi dan teknologi. Sebagai penyelenggara kelas online, madrasah akan mengelola berbagai kegiatan, seperti mengelola kelas, mengelola guru, mengelola siswa, pangkalan data, rekap atau jumlah penilaian dan aktifitas pembelajaran. Sebagai penyelenggara kelas online, madrasah dapat memantau sejauh mana pemanfaatan belajar di kelas online oleh guru dan siswa. Adapun beberapa poin manfaaat dari penggunaan kelas online adalah: (1) bahan ajar yang belum ataupun sudah disampaikan di kelas formal dapat disampaikan atau dibahas kembali di forum diskusi kelas online; (2) media untuk membantu dan meningkatkan ketuntasan belajar; (3) kelas alternatif pendukung dalam model-model pembelajaran; (4) sarana praktek pembelajaran; (5) strategi pembelajaran moderen; (6) meningkatkan kualitas belajar melalui smartphone/android; (7) menjadikan penggunaan smartphone/android sebagai sarana belajar yang efektif dan menyenangkan; (8) membantu siswa lebih aktif dalam proses pembelajaran. (9) membantu guru dalam penyampaian materi dengan berbagai variasi

\footnotetext{
${ }^{4}$ Munir, Pembelajaran Jarak Jauh, Berbasis Teknologi Informasi dan Komunikasi (Bandung: Alfabeta, 2009), 18; Yan Setiawan, Pemanfaatan Kelas Maya untuk Pembelajaran Daring (Jakarta: Kementerian Pendidikan dan Kebudayaan, 2018), 42.

${ }^{5}$ Winarno Winarno dan Johan Setiawan, "Penerapan Sistem E-Learning pada Komunitas Pendidikan Sekolah Rumah (Home Schooling)," Ultima InfoSys : Jurnal Ilmu Sistem Informasi 4, no. 1 (Juni, 2013): 46; Vera Dewi Kartini Ompusunggu dan Nilam Sari, "Efektifitas Penggunaan E-Learning Berbasis Edmodo terhadap Kemampuan Komunikasi Matematika," Jurnal Curere 3, no. 2 (November, 2019): 59.
} 
penyanyian materi. ${ }^{6}$ Berbagai pertimbangan dalam menentukan arah pendidikan atau kurikulum di masa darurat Covid-19 ini untuk mencapai tujuan sekolah sesuai dengan fungsinya maka memaksimalkan potensi guru dan ketersediaan media pendukung dalam pembelajaran online adalah trending topic yang harus diperhatikan oleh madrasah khususnya MTs N 1 Kotamobagu.

Kebijakan belajar dari rumah melalui pembelajaran online sebagai alternatif pencegahan penyebaran corona virus disease (Covid-19) sebagaimana pada prawacana sebelumya, tentunya hal ini menimbulkan tantangan baru bagi guru-guru MTs N 1 Kotamobagu. Guru-guru sebisa mungkin menyusun rencana pelaksanaan pembelajaran pada kurikulum darurat Covid-19 agar proses pembelajaran tetap terlaksana walaupun pembelajaran dilakukan secara online. Ruang belajar dipindahkan di rumah, siswa-siswi madrasah harus menyadari dan merasa bahwa mereka sedang belajar. Pembelajaran dilakukan dengan menggunakan berbagai macam aplikasi seperti Ruang Guru, Classroom, Zoom, Google Doc, Google Form, maupun melalui grup WhatsApp. Di sisi lain, jaringan internet yang belum merata di pelosok negeri menyebabkan tidak semua daerah dapat menikmati internet. Hal yang sama juga terjadi di Kota Kotamobagu, beberapa daerah mengalami kesulitan dalam mengakses jaringan internet, sehingga menyebabkan proses pembelajaran online tidak terlaksana dengan baik.

Home visit adalah salah satu solusi mengatasi kesulitan belajar siswa dan merupakan tindakan preventif mengurangi miskomunikasi antara guru dan siswa dalam pembelajaran online. Home visit, metode ini mirip seperti kegiatan belajar mengajar yang disampaikan saat home schooling, meskipun pada awalnya istilah home visit lebih akrab dikenal pada persoalan kesehatan dan bimbingan konseling terhadap pasien, tetapi dalam perkembangannya menjadi pilihan utama dalam mengatasi persoalan yang muncul pada dunia pendidikan di masa pandemi Covid-19 saat ini. Guru mengadakan home visit atau melakukan kunjungan di rumah siswa dalam waktu tertentu. Home visit dilakukan jika pembelajaran online tidak terlaksana dengan baik. Home visit juga sebagai layanan responsif, yang merupakan layanan bantuan untuk siswa yang menghadapi permasalahan dan membutuhkan bantuan dengan segera, hal ini dilakukan agar siswa tidak mengalami hambatan dalam proses pembelajaran. Pelaksanaan home visit memerlukan persiapan dan perencanaan yang matang dari guru pembimbing dan memerlukan kerja sama yang baik dengan orang tua siwa serta atas persetujuan kepala sekolah. Dalam kegiatan ini guru mengambil peran sebagai pembimbing para siswa agar lebih meningkatkan potensi dirinya. Bimbingan yang dilakukan oleh guru tidak hanya untuk siswa yang mengalami permasalahan tapi juga pada semua siswa, agar tiap siswa semakin tinggi motivasi belajarnya sehingga dapat meningkatkan prestasi belajarnya. Home visit juga bertujuan untuk

\footnotetext{
${ }^{6}$ Vera Rahma Putri, "Memaksimalkan Kompetensi Guru Melalui Fitur Kelas Maya dalam Pembelajaran Bahasa Arab sebagai Inovasi Pembelajaran Jaman Now," Proceeding IAIN Batusangkar 3, no. 1 (Januari, 2019): 331.
} 
mempermudah guru mendapatkan informasi berbagai kegiatan yang dilakukan oleh siswa ketika berada di rumah. Disamping itu, orang tua siswa juga akan memperoleh informasi tentang tingkat keberhasilan anaknya ketika di sekolah. Sebagai penegasan bahwa home visit dilakukan dalam rangka menjalin kerjasama dengan orangtua siswa untuk menganalisa tentang gaya belajar, ibadah, serta kesulitan-kesulitan belajar pada siswa. ${ }^{7}$ Hal inilah yang diterapkan oleh MTs N 1 Kotamobagu sebagai refleksi pada kurikulum darurat di masa Covid-19.

\section{Metode Penelitian}

Pada penelitian ini, penulis melakukan eksplanasi pedagogik dengan paradigma positivistik, yakni eksplanasi secara sistematis menunjukkan hubungan antara berbagai butir informasi yang nampak beragam. ${ }^{8}$ Eksplanasi sampai tingkatan tertentu adalah mirip dengan inferensi (kesimpulan), karena keduanya diturunkan dari berbagai premis yang mendahuluinya. ${ }^{9}$ Pada kebijakan madrasah dalam kegiatan home visit sebagai refleksi kurikulum darurat Covid19 dengan mengukur tingkat kesiapan guru, respon siswa, materi dan hasil belajar melalui skala pengukuran atau rating scale penelitian kualitatif deskriptif. Data yang diperoleh juga sebagai evaluasi dan supervisi madrasah tentang efektifitas proses pembelajaran, mengingat terdapat berbagai fenomena yang dihadapi oleh guru dan siswa dalam pembelajaran online dan home visit yang dilakukan. Evaluasi yang digunakan adalah evaluasi model South Carolina, evaluasi yang dilakukan untuk menilai suatu program, aktivitasaktivitas yang dilaksanakan, serta pelaksanaan-pelaksanaannya guna membuat keputusan atau mengambil langkah-langkah tertentu di waktu mendatang. ${ }^{10}$ Maka dengan demikian penting kiranya hal ini untuk dilaporkan dalam paparan ilmiah, karena dari sisi urgensi dinilai penting sebagai bahan pertimbangan demi tercapainya tujuan pembelajaran dan dari segi seriousness, hal tersebut dianggap gawat untuk ditindak lanjuti, guna evaluasi proses dalam meningkatkan pelayanan pendidikan dan pengajaran di MTs N 1 Kotamobagu pada masa Covid-19.

\footnotetext{
${ }^{7}$ Husna Amalia, "Implementasi Home Visit dalam Upaya Meningkatkan Pembelajaran PAI di SDIT Al-Azhar Kediri," Didaktika Religia 4, no. 1 (April, 2016): 80-81.

${ }^{8}$ C. K. Wijaya, "Arti Eksplanasi Menurut Perspektif Filsafat Ilmu Ernest Nagel" (Tesis, Universitas Gadjah Mada, 1999), 16.

${ }^{9}$ Heri Santoso dan Cuk Ananta Wijaya, "Kritik Atas Eksplanasi Deduktif-Nomologis dalam Ilmu Sejarah," Jurnal Filsafat 13, no. 1 (April, 2007): 2.

${ }^{10}$ South Carolina Departement of Education, The South Carolina Comprehensive Developmental Guidance dan Counseling Program Model: A Guide for School Counseling Programs, Prekindergarten Through Grade Twelve (Columbia: South Carolina Department of Education, 2008), 36.
} 


\section{Pengertian Home Visit}

Menurut Roopnarine dan Johnson, program home visit memiliki tahapantahapan yang terdiri dari tiga tahapan. Pertama, intervensi langsung. Tahap ini berfokus pada kemajuan perkembangan siswa, tinjauan dan demonstrasi kegiatan yang akan dilakukan di rumah, praktik dan demonstrasi ulang oleh orangtua, serta diskusi mengenai tujuan dan hasil yang diharapkan dari semua tugas. Kedua, interaksi informal. Pada tahapan ini, petugas home visit memberikan informasi penilaian, kurikulum yang penting dan rencana kegiatan. Ketiga, upaya dukungan keluarga. Pada tahap ini, petugas home visit berperan sebagai pendengar bagi orang tua, memberikan informasi dan bantuan yang tepat dan memperoleh kepercayaan serta hubungan baik dengan orang tua siswa. ${ }^{11}$ Pada pembahasan yang lain, Prayitno menjelaskan bahwa home visit adalah salah satu teknik mengumpulkan data dengan cara mengunjungi rumah siswa untuk membantu menyelesaikan masalah yang dihadapi siswa. Senada dengan hal tersebut dalam penjelasan terkait menyebutkan bahwa home visit juga merupakan kegiatan untuk mendapatkan data yang berhubungan dengan keterangan dan kemudahan bagi penyelesaian permasalahan siswa dengan berkunjung ke rumah siswa. Tentunya kegiatan ini membutuhkan kerjasama yang aktif dari orang tua dan siswa itu sendiri. Home visit dilakukan setelah siswa memahami dan menyetujui kegiatan tersebut. ${ }^{12}$

Home visit mempunyai dua tujuan, yaitu untuk mendapatkan keteranganketerangan atau data yang dibutuhkan dalam memahami lingkungan dan kondisi belajar siswa, dan untuk memecahkan permasalahan siswa yang mengalami kesulitan dalam belajar. Pada tinjauan yang lain juga dijelaskan bahwa tujuan home visit di antaranya adalah: membangun hubungan antara lembaga keluarga, sekolah dan masyarakat; mengumpulkan data yang berharga tentang latar belakang kehidupan anak dan keluarganya, mengumpulkan data dapat berarti mendapat data baru atau mengecek betul tidaknya data yang diperoleh melalui metode lain; lebih mengenal lingkungan hidup siswa sehari-hari, bila informasi yang dibutuhkan tidak dapat diperoleh melalui angket dan wawancara informasi; untuk membicarakan kasus seorang siswa bila memerlukan kerjasama dengan orang tua.

Home visit merupakan layanan pendukung kegiatan bimbingan dan konseling yang dilakukan oleh guru pembimbing dengan mengunjungi siswa di rumah. Kegiatan yang dilakukan pada kunjungan rumah dapat berupa pengamatan dan wawancara, terutama terkait kondisi rumah tangga, fasilitas belajar dan hubungan antar anggota keluarga dalam kaitannya dengan

\footnotetext{
${ }^{11}$ Roopnarine dan Johnson, Pendidikan Anak Usia Dini dalam Berbagai Pendekatan (Jakarta: Kencana Prenamedia Group, 2009), 67.

${ }^{12}$ Prayitno, Dasar-Dasar Bimbingan dan Konseling (Jakarta: PT Rineka Cipta, 2013), 18; Puji Gusri Hdanayani dan Hafiz Hidayat, "Pentingnya Pelaksanaan Home Visit Oleh Guru Bimbingan dan Konseling," in Seminar Nasional Bimbingan dan Konseling Jambore Konseling 3, vol. 3 (Dipresntasikan pada Seminar Nasional Bimbingan dan Konseling Jambore Konseling 3, Pontianak: Ikatan Konselor Indonesia (IKI), 2018), 171.
} 
permasalahan siswa. Hubungan kerjasama antara guru dan orang tua siswa disebut dengan hubungan edukatif. Adanya kerjasama antara orang tua siswa dan guru merupakan bagian dari hubungan edukatif dalam rangka mendidik siswa sehingga siswa dapat memiliki kemampuan akademik dan perilaku yang baik. Hubungan edukatif ini diharapkan dapat mewujudkan persamaan prinsip dalam mendidik siswa sehingga siswa tidak mengalami kesulitan dengan adanya pola pendidikan yang berbeda antara belajar di rumah dan di sekolah. ${ }^{13}$ Fungsi utama kegiatan home visit adalah fungsi pemahaman. Dapat juga di telaah bahwa home visit perlu dilakukan dalam rangka membantu menangani masalah siswa walaupun tidak berlaku untuk seluruh siswa. Maksudnya, hanya siswa tertentu yang menurut perkiraan guru pembimbing perlu dilakukan kunjungan rumah, mengingat pemecahan masalah hanya dapat diselesaikan bila ada kontak dengan orang tua atau diperkirakan masalahnya bersumber dari lingkungan keluarga. Pertimbangan diperlukannya kunjungan rumah, sebagai berikut: (1) jika permasalahan yang dihadapi siswa ada sangkutpautnya dengan masalah keluarga; (2) keluarga sebagai salah satu sumber data yang dapat dipercaya tentang keadaan siswa; (3) dalam kegiatan bimbingan diperlukan kerjasama antara guru pembimbing dengan orang tua; (4) faktor situasi keluarga memegang peranan penting terhadap perkembangan dan kesejahteraan anak. ${ }^{14}$ Program home visit tidak hanya menggunakan pendekatan teoritis, namun juga dapat menggunakan pendekatan praktis. Program ini melayani berbagai tingkatan usia anak, status keluarga, berbagai layanan yang ditawarkan, intensitas kunjungan rumah, dan isi dari kurikulum yang digunakan. ${ }^{15}$

Pelaksanaan program home visit dilaksanakan dalam 3 tahap yaitu perencanaan, pelaksanaan dan evaluasi. Tahapan tesebut perlu dijalani agar home visit dapat terlaksana dengan efektif dan efisien. Dalam pelaksanaan home visit guru juga perlu memperhatikan berbagai hal yang mempengaruhi agar tidak terjadi kesalahpahaman antara pihak sekolah dan orang tua siswa. Apabila sudah terjadi kesalahpahaman maka kegiatan home visit akan sia-sia dan memungkinkan munculnya masalah baru yang menyebabkan kurangnya kepercayaan orang tua siswa kepada pihak sekolah. Keberhasilan dari program home visit dapat didukung oleh keterlibatan keluarga, orang tua dan guru yang secara aktif dan professional. Interaksi langsung secara efektif antara keluarga dan guru dapat meningkatkan motivasi belajar siswa agar mengalami perubahan pada hasil belajar. ${ }^{16}$

\footnotetext{
${ }^{13}$ Purwanto Ngalim, Administrasi dan Supervisi Pendidikan (Bandung: PT Remaja Rosadakarya, 1998), 194.

${ }^{14}$ Indah Perdana Sari, "Mengapa Home Visit?," diakses pada tanggal 14 November 2020 dari https://almaata.ac.id/mengapa-home-visit/.

${ }^{15}$ Elis Komalasari, "Layanan Home Visit Pendidikan Anak Usia Dini Bagi Anak Kurang Sejahtera," Ta'dib 18, no. 1 (Oktober, 2016): 80.

${ }^{16}$ Bernardinus Agus Arswimba, "Evaluasi Pelaksanaan Home Visit di SMP," Jurnal Selaras : Kajian Bimbingan dan Konseling serta Psikologi Pendidikan 1, no. 2 (2018): 114; Konita Dian
} 


\section{Home Visit sebagai Refleksi Kurikulum Darurat Covid-19}

"Home visit are made as part ot the work of some members of the school staff. The home visitor, the schoolnurse, the school physician, and the secondary school level agriculture and home economics teacher are expected to make visit to the homes of the are students as a routine part of the school procedure. All the individuals mention may provide valuable information for classroom teacher."17

Kutipan tersebut menyatakan bahwa home visit dilakukan sebagai bagian dari kerja reguler beberapa staf sekolah, seperti pengunjung rumah, perawat sekolah, dokter sekolah, dan petugas presensi (kehadiran) yang bisa mengunjungi rumah siswa sepanjang tahun ajaran. Di MTs N 1 Kotamobagu, program home visit juga dilakukan oleh guru atau wali kelas bersama dengan guru pendamping baik itu guru bimbingan konseling dan dokter atau perawat sekolah. Melaksanakan home visit dengan baik membantu guru dalam rangka meningkatkan hasil belajar siswa, karena hal tersebut telah terprogram dengan jelas apa yang akan dilakukan. Kegiatan ini dilakukan guru untuk mendapatkan data dan keterangan siswa serta memahami permasalahan siswa secara tepat. Hasil kegiatan tersebut dapat digunakan dalam memberikan informasi pencapaian siswa selama belajar dari rumah, sehingga siswa dapat mengembangkan potensinya secara maksimal. Perolehan hasil home visit kemudian di evaluasi dan ditindak lanjuti demi kepentingan penyelesaian permasalahan siswa selama belajar dari rumah di masa pandemi Covid-19 ini.

Berdasarkan rekapitulasi data kesiapan guru MTs N 1 Kotamobagu dalam program home visit dapat dideskripsikan bahwa jumlah skor kriterium (bila setiap butir mendapat skor tertinggi) $=4 \times 6 \times 40=960$. Untuk skor tertinggi $=$ 4 , jumlah butir $=6$, dan jumlah responden $=40$. Jumlah skor hasil pengumpulan data $=769$, dengan demikian dapat diketahui bahwa tingkat kesiapan guru dalam menyediakan media elektronik seperti handphone dan laptop sebagai media pendukung dalam pembelajaran online dan proses pembelajaran pada program home visit serta kesiapan materi, dan pemberian tugas kepada siswa adalah $769: 960=80,10 \%$. Nilai 769 termasuk dalam kategori interval "sering (SR) dan selalu (SL)" tetapi lebih mendekati kategori sering (SR). Hal ini dapat disimpulkan bahwa guru Madrasah Tsanawiyah Negeri 1 Kotamobagu dengan kategori 80,10 \% sering mempersiapkan media, materi dan strategi terlebih dahulu dalam proses pembelajaran pada pogram home visit yang dilakukan selama masa pandemi Covid-19.

\footnotetext{
Dwita, Ade Irma Anggraeni, dan Haryadi Haryadi, "Pengaruh Home Visit dan Motivasi Belajar terhadap Hasil Belajar Siswa di SDIT Harapan Bunda Purwokerto," Jurnal Ekonomi, Bisnis, dan Akuntansi 20, no. 1 (2018): 3; Eddy Abdullah, "Home Visit oleh Guru atau Wali Kelas dan Motivasi Belajar Siswa,” Jurnal Kajian Pembelajaran dan Keilmuan 3, no. 2 (Oktober, 2019): 143.

${ }^{17}$ Barr John, The Elemtaryteacher dan Guidance (New York: Holt Rihenrt dan Winston, 1954), 238.
} 
Rekapitulasi data respon siswa MTs N 1 Kotamobagu dalam program home visit juga dapat dideskripsikan bahwa jumlah skor kriterium (bila setiap butir mendapat skor tertinggi) $=4 \times 13$ × $272=14144$. Untuk skor tertinggi $=$ 4 , jumlah butir $=13$, dan jumlah responden $=272$. Jumlah skor hasil pengumpulan data $=11198$, dengan demikian dapat diketahui bahwa respon siswa terhadap kebijakan MTs N 1 Kotamobagu tentang pelaksanaan program Home visit pada proses pembelajaran di masa Covid-19 adalah $11198: 14144=$ $79,17 \%$. Hal ini secara kontinum dapat dibuat kategori sebagai berikut:

\section{4}

\section{J KD SR 11198 SL}

Nilai 11198 termasuk dalam kategori interval "sering (SR) dan selalu (SL)" tetapi lebih mendekati kategori sering (SR). Hal ini dapat disimpulkan bahwa siswa-siswi Madrasah Tsanawiyah Negeri 1 Kotamobagu dengan kategori 79,17 \% sering merespon dengan baik program home visit yang dilaksanakan oleh guru-guru Madrasah Tsanawiyah Negeri 1 Kotamobagu sebagai alternatif proefektifitas pembelajaran di masa pandemi Covid-19. Hal tersebut tercermin dalam pemahaman siswa terhadap program home visit, kesiapan siswa dalam menyiapkan media pendukung proses pembelajaran dan keaktifan siswa serta sikap senang yang ditunjukan siswa selama guru melakukan home visit.

Pada hasil penelitian juga diketahui tingkat kepedulian orang tua dalam memberikan informasi tentang aktivitas dan perkembangan siswa selama belajar di rumah dan peran orang tua dalam membantu guru mendampingi dan mengawasi siswa selama pelaksanaan home visit. Berdasarkan data yang diperoleh dapat dideskripsikan bahwa jumlah skor kriterium (bila setiap butir mendapat skor tertinggi) $=4$ × 4 × $312=4992$. Untuk skor tertinggi $=4$, jumlah butir $=4$, dan jumlah responden $=312$. Jumlah skor hasil pengumpulan data $=$ 4296. Maka tingat kepedulian orang tua terhadap pelaksanaan program home visit adalah $4296: 4992=86,05 \%$. Selain itu, tingkat kepatuhan guru dan siswa dalam memperhatikan protokoler kesehatan Covid-19 selama pelaksanaan home visit adalah 4 × 1 x $312=1248$. Untuk skor tertinggi $=4$, jumlah butir $=1$, dan jumlah responden $=312$. Jumlah skor hasil pengumpulan data $=1148$. Dengan demikian dapat diketahui presentase kepatuhan guru dan siswa terhadap protokoler kesehatan Covid-19 yang dapat dilihat dari intensitas penggunaan masker, mencuci tangan dan tetap menjaga jarak selama pelaksanaan home visit adalah $1148: 1248=91,98 \%$.

Charta data terpilih menginformasikan bahwa materi pelajaran yang disampaikan atau diajarkan guru kepada siswa selama proses pembelajaran online dan home visit yang dilakukan hanya $65 \%$ dari target yang diharapkan. Selain itu, rata-rata perolehan nilai pada tes hasil belajar siswa adalah 78,59 dengan presentase target pencapaian hasil belajar adalah 69. Data tersebut 
menguatkan informasi yang penulis dapatkan bahwa pelaksanaan home visit membantu guru dalam mendapatkan informasi tentang keluhan siswa dan orang tua selama pembelajaran jarak jauh dimasa pandemi Covid-19. Home visit sebagai ajang silaturohim antara siswa, guru dan orang tua siswa. Guru mudah memberikan informasi kepada orang tua tentang kurangnya interaksi sosial siswa selama di madrasah. Siswa yang tinggal di pedesaan dan tidak dapat mengikuti pembelajaran online merasa terbantukan dengan adanya program home visit. Home visit juga dilakukan untuk menghindari kerumunan siswa di madrasah sehingga tidak terjadi cluster baru dalam penyebaran Covid19. Selain itu, dalam pelaksanaannya terdapat beberapa faktor yang menghambat diantaranya; Home visit kurang maksimal karena rasio jumlah guru dan siswa tidak seimbang. Guru hanya bisa sekali dalam satu bulan melakukan home visit pada 1 orang siswa. Pelaksanaan home visit juga menguras banyak tenaga dan menyita waktu, mengingat rumah tempat tinggal siswa memiliki jarak tempuh yang berbeda-beda.

\section{Kesimpulan}

Berdasarkan hasil penelitian maka dapat disimpulkan sebagai berikut. Pertama, pelaksanaan home visit membantu guru dalam mendapatkan informasi tentang kendala yang dialami siswa dan orang tua selama pembelajaran jarak jauh dimasa pandemi Covid-19. Home visit juga memudahkan siswa yang tidak dapat mengikuti pembelajaran online untuk mendapatkan materi pelajaran. Kedua, pada pelaksanaan home visit dapat diketahui bahwa guru Madrasah Tsanawiyah Negeri 1 Kotamobagu memiliki tingkat kesiapan dengan kategori $80,10 \%$ guru siap dalam pelaksanaan home visit dengan respon siswa terhadap program home visit 79,17\% siswa merespon dengan baik, sementara materi pelajaran hanya $65 \%$ yang tersampaikan dari target yang diharapkan dengan presentase target pencapaian hasil belajar 69\%. Selain itu, tingkat kepedulian orang tua dalam memberikan informasi tentang aktivitas dan perkembangan siswa selama belajar di rumah dan peran orang tua dalam membantu guru mendampingi dan mengawasi siswa selama pelaksanaan home visit adalah $86,05 \%$ dan $91,98 \%$ guru dan siswa patuh memperhatikan protokoler kesehatan Covid-19 selama pelaksanaan home. visit. Pada pelaksanaan pembelajaran di masa darurat Covid-19 yang dilakukan melalui pembelajaran online, guru harus berupaya lebih inovatif mendorong kreatifitas dan kemandirian siswa madrasah dalam proses pembelajaran. Selain itu, koordinasi antara guru dan madrasah mengenai ketersediaan media pendukung pembelajaran online harus ditindak lanjuti dengan segera agar pelayanan pendidikan madrasah dapat terlaksana dengan baik dan produktif.[] 


\section{Daftar Pustaka}

Abdullah, Eddy. "Home visit Oleh Guru atau Wali Kelas dan Motivasi Belajar Siswa." Jurnal Kajian Pembelajaran dan Keilmuan 3, no. 2 (Oktober, 2019): 142-149.

Amalia, Husna. "Implementasi Home visit dalam Upaya Meningkatkan Pembelajaran PAI di SDIT Al-Azhar Kediri.” Didaktika Religia 4, no. 1 (April, 2016): 77-106-106.

Arswimba, Bernardinus Agus. "Evaluasi Pelaksanaan Home Visit di SMP." Jurnal Selaras: Kajian Bimbingan dan Konseling serta Psikologi Pendidikan 1, no. 2 (2018): 111-120.

Dwita, Konita Dian, Ade Irma Anggraeni, dan Haryadi Haryadi. "Pengaruh Home Visit dan Motivasi Belajar terhadap Hasil Belajar Siswa di SDIT Harapan Bunda Purwokerto." Jurnal Ekonomi, Bisnis, dan Akuntansi 20, no. 1 (2018): 1-15.

Handayani, Puji Gusri, dan Hafiz Hidayat. "Pentingnya Pelaksanaan Home Visit oleh Guru Bimbingan dan Konseling." Dalam Seminar Nasional Bimbingan dan Konseling Jambore Konseling 3, 3:168-177. Pontianak: Ikatan Konselor Indonesia (IKI), 2018.

John, Barr. The Elemtaryteacher and Guidance. New York: Holt Rihenrt and Winston, 1954.

Kementerian Kesehatan RI. Pedoman Pencegahan dan Pengendalian

Coronavirus Disease (Covid-19) Revisi Ke-4. Direktorat Jenderal Pencegahan dan Pengendalian Penyakit (P2P), 2020.

Komalasari, Elis. "Layanan Home visit Pendidikan Anak Usia Dini Bagi Anak Kurang Sejahtera." Ta'dib 18, no. 1 (Oktober, 2016): 76-85.

Munir. Pembelajaran Jarak Jauh, Berbasis Teknologi Informasi dan Komunikasi. Bandung: Alfabeta, 2009.

Ngalim, Purwanto. Administrasi dan Supervisi Pendidikan. Bandung: PT Remaja Rosadakarya, 1998.

Nurhayati, dkk. Rancangan Model Pembelajaran Kelas Maya Melalui Rumah Belajar Sebagai Program Remedial. Jakarta: Pusat Teknologi Informasi dan Komunikasi Pendidikan dan Kebudayaan, 2018.

Ompusunggu, Vera Dewi Kartini, dan Nilam Sari. "Efektifitas Penggunaan ELearning Berbasis Edmodo terhadap Kemampuan Komunikasi Matematika." Jurnal Curere 3, no. 2 (November, 2019): 58-66.

Prayitno. Dasar-Dasar Bimbingan dan Konseling. Jakarta: PT Rineka Cipta, 2013. 
Putri, Vera Rahma. "Memaksimalkan Kompetensi Guru Melalui Fitur Kelas Maya dalam Pembelajaran Bahasa Arab Sebagai Inovasi Pembelajaran Jaman Now." Proceeding IAIN Batusangkar 3, no. 1 (Januari, 2019): 323332.

Rahman Abdur, Assegaf. Pendidikan Islam di Indonesia. Yogyakarta: Suka Press, 2017.

Roopnarine, and Johnson. Pendidikan Anak Usia Dini dalam Berbagai Pendekatan. Jakarta: Kencana Prenamedia Group, 2009.

Santoso, Heri, dan Cuk Ananta Wijaya. "Kritik Atas Eksplanasi DeduktifNomologis dalam Ilmu Sejarah.” Jurnal Filsafat 13, no. 1 (April, 2007): $1-14$.

Sari, Indah Perdana "Mengapa Home Visit?." Diakses pada tanggal 14 November 2020 dari https://almaata.ac.id/mengapa-home-visit/.Setiawan,

Yan. Pemanfaatan Kelas Maya Untuk Pembelajaran Daring. Jakarta:

Kementerian Pendidikan dan Kebudayaan, 2018.

South Carolina Departement of Education. The South Carolina Comprehensive Developmental Guidance and Counseling Program Model: A Guide for School Counseling Programs, Prekindergarten Through Grade Twelve. Columbia: South Carolina Department of Education, 2008.

Terry, Anderson. The Theory and Practice of Online Learning. 2nd ed. Edmonton: Athabasca University Press, 2008.

Wijaya, C. K. "Arti Eksplanasi Menurut Perspektif Filsafat Ilmu Ernest Nagel." Tesis, Universitas Gadjah Mada, 1999.

Winarno, Winarno, dan Johan Setiawan. "Penerapan Sistem E-Learning pada Komunitas Pendidikan Sekolah Rumah (Home Schooling)." Ultima InfoSys : Jurnal Ilmu Sistem Informasi 4, no. 1 (Juni, 2013): 45-51. 